\title{
CONCEPTUAL LANDMARKS ON THE EVOLUTION OF MILITARY ART
}

\author{
Marian HOGEA \\ “Nicolae Bălcescu" Land Forces Academy, Sibiu, Romania \\ marianhogea1@gmail.com
}

\begin{abstract}
Military art is the fundamental component of military science and has as its object the war as a whole and the armed struggle. Over the years, military art has seen spectacular evolutions and mutations in strategy, operative art and tactics, by assimilating and integrating the achievements of the technical-scientific revolution. From this perspective, we aim to highlight the main conceptual landmarks in which military art evolved also targeting the high technology, network-based warfare, the planned operation on the effects of using ISTAR systems and the hybrid operation that integrates and associates several military and non-military components. This comprehensive approach to the evolution of military art gives us the possibility to evaluate the multidimensional operational environment, to highlight the characteristics and physiognomy of the future military operations through the integration of new technological and information systems and equipment. In this context, we state that the success in planning, training, execution and evaluation of military operation in the future will depend on the professionalism of the human resource and the degree of assimilation of technologies and intelligent systems within the management and execution structures. In recent years, the art of war has undergone major changes at all levels (strategic, operational and tactical). Due to the new information phase of the scientific and technological revolution, in the near future, several theories of armed struggle will arise influencing the social and economic life of all states.
\end{abstract}

\section{Keywords: ISTAR, Weapons, Military logistics, Communications}

The global crisis at the beginning of the $21^{\text {st }}$ century has also made its mark in the field of international military art, limiting as much as possible exercises, naval and aeronautical operations, leaving deep and inexcusable traces of military professionalism.

We can say that in recent years, the history of military art evolution at the international level is one of the most tragic and at the same time heroic themes in the history of modern global military policy. On the one hand, it can be argued that in the field of military art, i.e. the development of methods and forms of use of military force, for many years we have noticed its degradation and, on the other hand, at tactical level new methods have been developed and sometimes significant progress has been made in the field of military art. Unfortunately, these developments have been done with much blood in the conflicts in Korea (19501953), Afghanistan (1979-1989), Falklands 1982, Iraq 2003, Georgia 2008 and last but not least Crimea 2014.

Contemporary military conflicts have highlighted new orientations and concepts of military action, characterized by complexity, mobility, dynamism, the use 
of high technology and almost totally professionalized forces, integrated actions of all categories of arms and military branches. The space for the armed struggle in its terrestrial, air, maritime and cosmic dimension tends to become more integrated, fully cybernetic, with increasing tendencies to expand into the electromagnetic environment based on spectacular developments in the technicalscientific field.

Operations at strategic level target national or alliance/coalition objectives - in multinational operations.

To achieve the strategic military objectives, campaign operations (strategic level operation)are carried out.

Achieving the strategic goals requires the following requirements to be met:

$\checkmark$ identification of strategic military objectives, definition and approval of campaign objectives to ensure success;

$\checkmark$ identification of political, financial or legal limitations imposed by the use of forces;

$\checkmark$ defining the capabilities of strategic force and reserve;

$\checkmark$ establishing the command line and financial resources and supporting materials;

$\checkmark$ analysis of military risks.

Elements with a power to modify the military phenomenon:

- phasing and proportionality of the military action;

- reassessment of the post-conflict stage and the role of the army;

- designing, deploying and hiring multinational force;

- increasingly combining the political and military elements in the management of a crisis (conflict);

- the flexibility of the perpetual feature in the attitude of confrontation;
Reevaluating the objectives of the conflicts and the main ways and means used in the war, we can distinguish three distinct levels of the armed forces:

- modern armed forces that use stateof-the-art technologies (US, Russia, China and a number of other states) in their actions;

- armed forces of the traditional type, using the doctrine of mass army and military art used in the second half of the $20^{\text {th }}$ century (Ukraine, Turkey, Georgia, Syria, Iran, Iraq);

- irregular armed formations of nonstate actors acting both internationally and within their own countries (Afghanistan, Iraq, Yemen, Syria).

Starting from the changes in military art at the beginning of the twentieth century, we can consider World War I (July 28, 1914 November 11, 1918) the first beneficiary of the development of global science, technologically speaking. In the First World War, all scientific discoveries accumulated in the Renaissance era were put into practice. The novelty of this war in terms of military art was represented by the Position War or the Trenches War. The strategic balance reached by the European nations in the conflict had reached almost the same level, from which they could hardly get out

The influence of World War I on global politics is, as is said in mathematics, a point of bifurcation. Then everything has changed as a result of and, in particular due to, the political map of the world. All the major empires that existed on the European continent have disappeared and many new independent states have emerged [2].

Basically, this has been reflected in politics around the world - the world order has not been further defined by the great empires, but has developed on the principles that 
have declared sovereignty and the right of the people to form their own state [3].

World War II (1939-1945) had an even greater influence on military art due to technology, which played a crucial role in the outcome of World War II. Much of these technologies were developed in the interwar years, 1920-1930, some developed as a result of the lessons learned during the war and others towards the end of the war [4].

The areas that developed due to the second world conflagration were as expected, the battle technique and medicine, namely:

- Weapons: ships, vehicles, airplanes, missiles, artillery equipment, infantry weapons and atomic weapons.

- Military logistics: vehicles for the transport of soldiers and equipment (trucks, jeeps, ships, planes).

- Communications, espionage and counterintelligence: communication, navigation, remote detection and espionage equipment.

- Medicine: developing surgical techniques, discovering new medicines.

Due to the development of the fighting technique, a new concept, namely the blitzkrieg, which sustains a generalized military offensive, followed by massive air strikes and massive bombings, and at the end of the military operation high mobility forces are introduced.

Politically, in order to promote international stability and prevent future conflicts, the United Nations (UN) has been established. Victory powers - the United States, the Soviet Union, China, the United Kingdom and France have become permanent members of the UN Security Council [5]. Amid rivalry between the two superpowers, the United States and the Soviet Union have prepared the Cold War scene, which lasted for 46 years.
World War II changed the political alignment and social structure of the world. Against the backdrop of the Cold War, in 1948, NATO's political-military alliance was established, through which France, the United Kingdom, Belgium, the Netherlands and Luxembourg are committed to supporting each other in the event of war.

On March 20, 2003, the United States, in co-operation with 45 other countries, launched the war against Saddam Hussein's regime in Iraq, giving birth to the first war of the third millennium and contributing to strategic military development. Many military specialists claim that this war fits into a new concept, namely the military strategy of the future, introducing in the strategic concept a new form of war - the digitization of the battlefield and the integration of operations.

Today, command and control issues of troop and combat operations using automation equipment are closely related to information warfare [6].

"Network-based War" is based on the superiority of information on the enemy, which transforms into an overwhelming battle power by connecting intelligent objects (sensor networks, headquarters and executive locations) into a unique information space in the theater of operations. At the same time, the transformation of the concept of "battlefield" into the notion of "battle space", the concept of "network-based warfare" as virtual objectives, besides traditional ones, symbolizes human emotions, human psyche etc [7].

After a moment of peace and exploration, another military power makes its mark on military art, developing the hybrid war. This war is as dangerous as the classic one, 
leading to the occupation of a state or more, with a much greater number of victims. In the hybrid war, the weapons can defend until the end, but until then words are used, a propaganda bombardment, full of misinformation and manipulation in all the basic structures of a state. Most people do not perceive this type of war because it does not manifest physically at the moment of its emergence. As we mentioned earlier, the hybrid war weapon is the word. We hear the word every day, its present everywhere, in the world of communication, it is like it is alive, in printed shape, then by voice on the radio, in television and, more recently, it is uncontrollably multiplied into the infinite world of the Internet [8].

In conclusion, wars have always reflected the level of technological development, and in the modern post-industrial era, Western countries, especially the United States, are actively developing a new type of war model. This theory is called network wars. Attitude to the Internet or computer games is relative. Network warfare is a theory of the qualitative change of military technology and the structure of modern societies as a whole. Over time, people have learned collectively in the community, not how to save or help one another, but how to annihilate each other and possibly how to sustain themselves in order to survive, in order to stay alive, in conflicts. That is why military art seems to be, in a way, an art of death and, at the same time, the art of survival. Man, himself, is neither a hero, nor some random fellow, neither a fighter nor a pacifist. At least, that is how it should be. Man is simply a man, that is, a being who cares about his life, whose thoughts are stronger than life. Not because he wants it, or because it would be good, but because it was given to him. Man's life only makes sense if it is thought of as being in a system of common, social and moral values, and the community, society and morality means, above all, identity, differentiation, limitation, and thus struggle. That is the way things are and will always be. The disappearance of border differentiation means the disappearance of identity, information, the attainment of the ultimate degree, that of zero entropy. More precisely, motionless, that is, death [9].

The trends of evolution of the military art content are closely correlated with the evolution of the military phenomenon as a whole, and the military art constantly adapts its principles, methods, procedures and rules of preparation and conduction of the military actions so that they correspond to the organizational, structural changes and endowment, specific to the modern military system.

\section{REFERENCES}

[1] General dr. Popescu Mihail, General de brigadă (r) dr. GHEORGHE VĂDUVA, General locotenent (r)dr. Valentin Arsenie -Arta militară de-a lungul mileniilor,Editura CTEA, București 2004

[2] Alexander Tsyganov, cronicar ITAR-TASS

[3] Alexander Tsyganov, cronicar ITAR-TASS

[4] https://ro.wikipedia.org/wiki/Noi tehnologii \%C3\%AEn timpul_celui_de-al_Doilea_R\%C4\%83zboi_Mondial 18.022019 ora18.42 
[5] Herman Van Rompuy, President of the European Council; José Manuel Durão Barroso, President of the European Commission (10 decembrie 2012). „From War to Peace: A European Tale". Prelegerea în numele Uniunii Europene de la decernarea Premiului Nobel. Accesat în 4 ianuarie 2014.

[6] https://psyfactor.org/news/webwar.htm - 19.02201916 .50

[7] https://psyfactor.org/news/webwar.htm - 19.022019

[8] Marian Hogea - Războiul hibrid - un concept nou, sau o strategie veche de mii de ani? Caracterul hibrid și asimetric al acțiunilor militare contemporane.

[9] General dr. Popescu Mihail, General de brigadă (r) dr. GHEORGHE VĂDUVA -Arta militară de-a lungul mileniilor p.606 